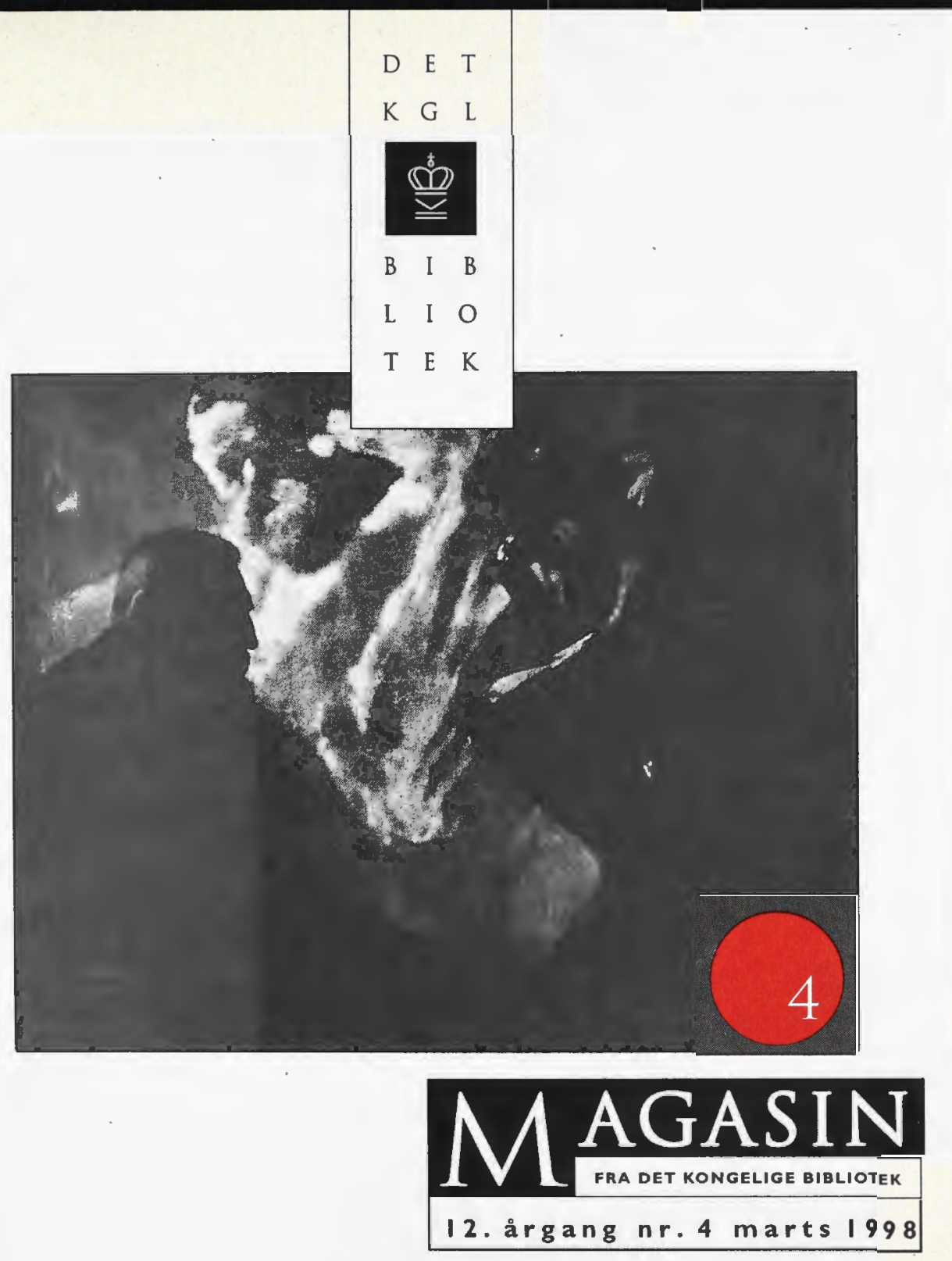


Dantes Plads: Utzon Frank, Carpeaux, Rodin.

\section{Ole Meyer}

Oplæg til en litterær skulpturvandring ved

Glyptoteket

Søren Gosvig Olesen

Tro, håb, kærlighed. En kierkegaardsk kommentar til André Comte-Sponvilles etik

Torben Meyer

Sådan blev biografien 'Carl Nielsen - Kunstneren og mennesket' til

Erland Kolding Nielsen og Niels Mark Pligtaflevering af kulturarven - hvorfor dog det?

Niels Krabbe Omkring Riisager-året 1997

Kronik (58)

Juli -september 1997

Publikationer (22)

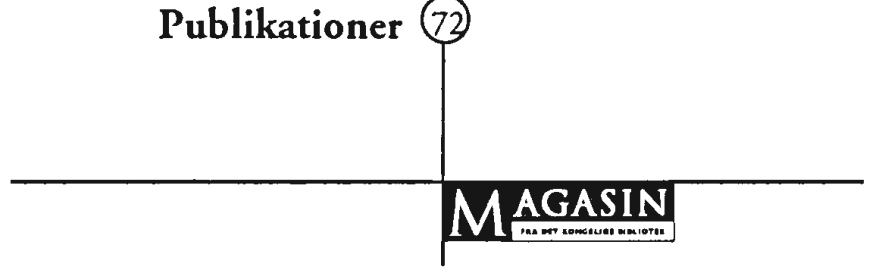

Udgiver:

Det kongelige Bibliotek

Redaktion og grafisk tilrettelæggelse:

Afdelingsbibliotekar Lotte Philipson

I redaktionen:

Direktør Erland Kolding Nielsen

Konceptdesign: Kontrapunkt A/S

Ekspedition:

Det Kongelige Bibliotek,

Postboks 2149, 1016 København K.

Tel: 33474747

Oplag: $3.800 \cdot$ Gratis

Tryk:

Det Kongelige Bibliotek

Hvor intet andet angives, er eftertryk tilladt med angivelse af kilde og evt. forfatter.

ISSN 0905-5533

Forsiden: Rodin, Hugo, Grubleren. Fotogravure af Edward Steichen, 1903. Billedet synes fremkommet ved delvis spejlvendt montage af de tre figurer, idet Hugo vises spejlvendt, Grubleren derimod retvendt. Kort- og Billedafdelingen. 


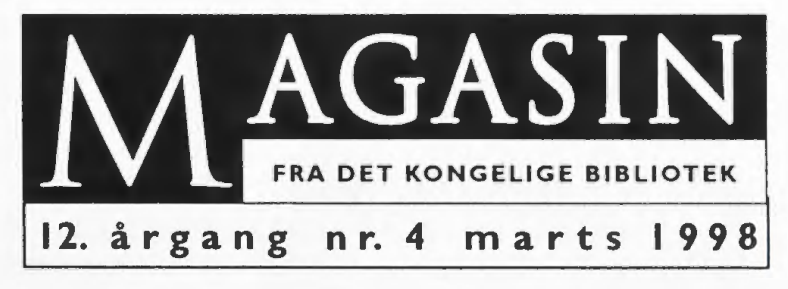

